\title{
PENERAPAN PENDIDIKAN JARAK JAUH (PJJ) DIMASA PANDEMI COVID-19 PADA SIDH BELANDA DAN SIKL MALAYSIA
}

\author{
Husni Mubarok ${ }^{1}$, Yasinta Indra Swastika ${ }^{2}$, Ayu Ainun ${ }^{3}$, Siti Umi Hamdanah", \\ Putri Diana Lestari ${ }^{5}$, Muhammad Alif Saifuddin ${ }^{6}$ \\ Institut Agama Islam Negeri Kudus \\ husnimubarok@iainkudus.ac.id, swastinta@gmail.com
}

\begin{abstract}
The covid-19 pandemic caused the elimination of all activities that are usually carried out by almost everyone in the world, especially learning activities at various levels. Based on the Higher Education Law number 12 of 2012, article 31 concerning Distance Education (PJJ) is a learning process that is carried out remotely through the use of various communication and information media. Therefore, since the covid outbreak, distance education is now widely applied in the learning process almost all over the world. This study aims to determine the application of distance education in SIDH Netherlands and SIKL Malaysia during the pandemic, and to find out the obstacles in the application of distance education in SIDH Netherlands and SIKL Malaysia during the pandemic. The method used in this research is descriptive qualitative method. Data collection techniques in this study using interview techniques. The results of the study state that SIDH in the Netherlands and SIKL Malaysia have implemented the PJJ (Distance Education) system since 2008, with Distance Learning being used to do this, automatically during this pandemic, students are not surprised by the online learning provided. teachers (educators), but there are also some obstacles faced during the teaching and learning process during the pandemic. Whereas in SIKL Malaysia, distance education was implemented when there was covid-19, so all students study at their respective homes. In its application, there are several obstacles in the learning process, one of which is signal constraints. The teachers from the two scools have coshen the best method for their students so that learning can be carried out optimally. And it is hoped that in learning to apply bealth protocols so that students and teacherscan carry out learning activities comfortably.
\end{abstract}

Keywords: Distance Education (PJJ), SIDH, SIKL, Covid-19

\begin{abstract}
Abstrak : Pandemi covid-19 menyebabkan ditiadakannya semua kegiatan yang biasanya dilakukan oleh setiap orang hampir di seluruh dunia, terutama kegiatan pembelajaran di berbagai jenjang. Berdasarkan Undang-Undang Perguruan Tinggi nomer 12 tahun 2012, pasal 31 tentang Pendidikan Jarak Jauh (PJJ) adalah suatu proses pembelajaran yang dilaksanakam secara jarak jauh melalui penggunaan berbagai media komunikasi dan informasi. Maka dari itu sejak adanya wabah covid ini, pendidikan jarak jauh sekarang banyak diterapkan dalam proses pembelajaran hampir di seluruh dunia. Penelitian ini bertujuan untuk mengetahui penerapan pendidikan jarak jauh di SIDH Belanda dan SIKL Malaysia pada masa pandemi, serta dapat mengetahui kendala dalam penerapan pendidikan jarak jauh di SIDH Belanda dan SIKL Malaysia pada masa pandemi. Metode yang digunakan dalam penelitian ini adalah metode deskriptif kualitatif. Teknik pengumpulan data dala penelitian ini menggunakan teknik wawancara. Hasil penelitian menyatakan bahwa di SIDH Belanda dan SIKL Malaysia menerapkan sistem PJJ (Pendidikan Jarak Jauh) sejak tahun 2008, dengan sudah terbiasanya dilakukan Pembelajaran Jarak jauh,
\end{abstract}

Islamika : Jurnal Keislaman dan Ilmu Pendidikan

Volume 3, Nomor 1, Januari 2021; 82-96

https://ejournal.stitpn.ac.id/index.php/islamika 
otomatis di masa pandemi ini ini peserta didik tidak kaget dengan adanya pembelajaran via online (daring) yang diberikan guru (pendidik), tetapi juga terdapat beberapa kendala yang dihadapi ketika berlangsungnya proses belajar mengajar di masa pandemi. Sedangkan di SIKL Malaysia diterapkannya pendidikan jarak jauh ketika adanya covid-19, jadi semua peserta didik belajar di rumah masing-masing. Dalam penerapannya terdapat beberapa kendala dalam proses pembelajaran, salah satunya yaitu terkendala sinyal. Para guru dari kedua sekolah tersebut sudah memilih metode yang terbaik bagi murid - murid nya supaya pembelajaran dapat terlaksana dengan maksimal. Dan diharapkan pada pembelajaran menerapkan protokol kesehatan agar para siswa dan para guru dapat melakukan kegiatan pembelajaran dengan nyaman.

Kata Kunci: Pendidikan Jarak Jauh (PJJ), SIDH, SIKL, Covid-19

\section{PENDAHULUAN}

Pendidikan secara umum merupakan sesuatu yang memiliki pengaruh dalam pribadi seseorang, akalnya serta akhlaknya mulai dilahirkan hingga dia mati. Pendidikan meliputi semua sarana prasarana, baik disengaja seperti pendidikan di lingkungan keluarga ( rumah) dan pendidikan sekolah ataupun pendidikan dari pengaruh lingkungan masyarakat. Dalam pengertian ini pendidikan sama dengan pengertian dalam kehidupan yang dianggap sebagai sebuah proses pembelajaran dengan anggapan bahwa dimulai sejak lahir sampai ke liang lahat. Sedangkan pengertian pendidikan secara khusus adalah semua media yang dipergunakan untuk mengembangkan jasmani anak didik, akalnya dan untuk pembinaan akhlaknya dan hanya meliputi sarana khusus. Pendidikan menjadi sangat penting karena pendidikan sebagai pondasi segala perubahan yang hendak dilakukan setiap individu. Tanpa adanya pendidikan, manusia tidak dapat memahami sesuatu yang ada di bumi ini. Peran pendidikan sendiri yaitu melakukan perubahan terhadap perilaku manusia melalui proses pembelajaran, pelatihan, dan juga pengajaran. Jadi pendidikan merupakan suatu kebutuhan pokok bagi setiap orang. Karena begitu pentingnya suatu pendidikan bagi manusia, maka pemerintah mewajibkan pendidikan setidaknya selama 9 tahun dan disarankan lebih dari itu.

Berdasarkan Undang-Undang Perguruan Tinggi nomer 12 tahun 2012, pasal 31 tentang Pendidikan Jarak Jauh (PJJ) adalah suatu proses pembelajaran yang dilaksanakam secara jarak jauh melalui penggunaan berbagai media komunikasi dan informasi. PJJ akan memberikan layanan pendidikan kepada kelompok masyarakat yang tidak dapat 
mengikuti pendidikan secara tatap muka. Pendidikan jarak jauh merupakan suatu konsep pendidikan yang mungkin dapat dikatakan relatif sudah lama dikembangkan walaupun PJJ dibandingkan dengan jalur formal / tradisional dapat dikatakan lebih mudah. PJJ mempunyai potensi mengubah persepsi atau pemahaman masyarakat terhadap suatu pendidikan.

Sejak adanya covid-19 yang menyebar di berbagai belahan dunia, pendidikan Jarak Jauh sekarang banyak diterapkan dalam proses pembelajaran hampir di seluruh dunia, hal ini merupakan salah satu solusi yang banyak ditawarkan di dalam dunia pendidikan selama masa pandemi covid19. Sebab proses pembelajaran harus tetap berlangsung tidak boleh stuck. Berbagai metode dan strategi pendidikan dalam proses pembelajaran di uji cobakan sebagai solusi pembelajaran selama masa pendemi. Ada lembaga pendidikan yang secara pure menerapakan PJJ sepenuhnya dalamproses pembelajaran, akan tetapi ada juga lembaga sekolah yang menerapkan PJJ secara setengah-setengah.

Jadi, dalam penerapanya pakai sistem $50 \%$ dimana siswa yang dirasa rumahnya dekat dengan sekolah bisa melaksanakan proses pembelajaran secara langsung dan peserta didik yang rumahnya jauh bisa menggunakan model pembelajaran sistem PJJ. Dalam sistem ini juga peserta didik yang rumahnya dekat tidak bisa mengikuti pembelajaran secara langsung semua, sesuai degan protokol kesehatan yaitu physical distancing jadi tetap dibagi. Ambil contoh kasus misal dalam satu kelas terdapat 30 peserta didik 6 dari peseta didik ini rumahnya jauh jadi sesuai kebijakan yang

6 ini ikut pembelajaran jarak jauh, untuk peserta didik lainya yang berjumlah 24 mengikuti proses pembelajaran secara langsung akan tetapi di bagi menjadi 2 kloter lagi, dimana kloter 1 terdiri dari (12) peserta didik yang berangkat pagi dan kloter 2 (12) peserta didik berangkat siang.

Akan tetapi kebijakan seperti ini kembali lagi kepada peraturan dari suatu wilayah dalam lembaga pendidikan tersebut, dalam pandemi covid-19 ini kepala sekolah tidak punya wewenang penuh untuk menentukan bagaimana model pembelajaran yang diterapkan sebab kondisi di suatu wilayah sangat berbeda-beda. Ada wilayah yang memang memungkinkan untuk melaksanakan proses pembelajaran secara langsung menggunakan sistem 50\% seperti yang sudah dijelaskan, karena memang di wilayah 
tersebut jumlah kasus yang terpapar virus covid-19 sedikit bisa terkontrol dan menjalani kehidupan sehari-harinya tetap mematuhi protokol kesehatan. Tetapi ada juga wilayah yang memang sangat tidak memungkinkan melaksanakan pembelajaran secara langsung mengingat kondisi diwilayah tersebut mengharuskan masyarakatnya untuk stay at home dan melaksanakan semua kegiatannya dirumah tak terkecuali dalam proses pembelajaran.

Berdasarkan latar belakang masalah, tujuan dari penelitian ini adalah untuk mengetahui penerapan pendidikan jarak jauh di SIDH Belanda dan SIKL Malaysia pada masa pandemi, serta dapat mengetahui kendala dalam penerapan pendidikan jarak jauh di SIDH Belanda dan SIKL Malaysia pada masa pandemi.

\section{METODE PENELITIAN}

Penelitian ini dilakukan dengan menggunakan penelitian deskriptif kualiatif. Penelitian ini bertujuan untuk mengungkapkan kejadian (fakta), fenomena, dan keadaan yang ada selama proses penelitian berlangsung dengan menyediakan apa yang sebenarnya terjadi pada saat kegiatan pembelajaran berlangsung dengan sistem daring (pendidikan jarak jauh). Metode penelitian ini dimaksudkan untuk melihat penerapan yang dilakukan pada saat pembelajaran dengan pendidikan jarak jauh di masa pandemi covid-19 atau dengan sistem daring. Teknik pengumpulan data pada kegiatan KKL secara virtual ini menggunakan metode wawancara. Peneliti mewawancarai narasumber yaitu dari beberapa guru yang mengajar di SIDH (Sekolah Indonesia Deen Haag) dan SIKL (Sekolah Indonesia Kuala Lumpur) secara daring.

Subyek pada penelitian ini adalah peserta didik di SIDH (Sekolah Indonesia Deen Haag) Belanda dan SIKL (Sekolah Indonesia Kuala Lumpur) Malaysia. Penelitian ini dilaksanakan pada tanggal 19 Agustus 2020 dan 27 Agustus 2020. Sedangkan teknik analisa data yang peneliti lakukan menggunakan teknik analisis data interaktif. Peneliti melihat atau mengamati secara online bagaimana proses pembelajaran yang ada di antara kedua Sekolah tersebut selama masa pandemi yaitu di Sekolah Indonesia Den Haag di Belanda dan juga sekolah Indonesia Kuala Lumpur di Malaysia. 


\section{HASIL DAN PEMBAHASAN}

\section{Pengertian Pendidikan Jarak Jauh}

Di Indonesia, Kemendikbud (Kementrian Pendidikan dan Kebudayaan) sudah menerbitkan beberapa surat edaran mengenai pencegahan dan penanganan virus corona sebagai upaya untuk mencegah serta memutus rantai penyebaran covid-19 khususnya bagi warga sekolah dan masyarakat pada umumnya. Beberapa surat edaran tersebut yaitu pada Nomor 2 Tahun 2020 tentang Pencegahan dan Penanganan Covid-19 di Lingkungan Kementrian Pendidikan dan Kebudayaan, dan pada Nomor 4 Tahun 2020 tentang Pelaksanaan Kebijakan Pendidikan dalam Masa Darurat Penyebaran virus corona yang antara lain mengenai proses belajar dari rumah atau Pendidikan Jarak Jauh.

Menurut Setijadi (2005:1) PJJ adalah merupakan salah satu jenis pendidikan yang yang peserta didiknya berpisah atau berjarak dengan gurunya, jadi pembelajaran dilakukan secara tidak langsung atau tatap muka. Maka dari itu dalam proses pembelajaran jarak jauh dilakukan dengan perantara media. Dohmen dalam Keegan, 1990 mengartikan PJJ sebagai salah satu contoh pembelajaran yang menjadikan peserta didik lebih mandiri dan terogarnisasi secara terstruktur atau sistematis, dengan begini penyampaian materi, bimbingan atau pemantauan keberhasilan dari peserta didik dilakukan oleh kelompok guru yang masing-masing memiliki jawab sendiri dan tertentu. Menurut UU Nomor 20 Tahun 2003 tentang Sistem Pendidikan Nasional, Pasal 1 ayat 15 dijelaskan bahwa PJJ adalah proses belajar mengajar yang terjadi antara guru dengan peserta didik akan tetapi mereka terpisah oleh jarak sehingga dalam pembelajarannya menggunakan apasaja yang termasuk kedalam sumber belajar seperti media informasi, teknologi informasi dan komunikasi dan lain.

Pendidikan Jarak Jauh (PJJ) bisa juga disebut dengan E-learning, Apa itu Elearning? Horton dalam E-Learning by Design (Cecep Kustandi, 2020) menjelaskan "Elearning is the use of information and computer technologies to create learning experience" yang jika diartikan "Elearning adalah penggunaan teknologi informasi dan komputer untuk menciptakana pengalaman belajar" sederhanaya pemebelajaran dapat dilakukan dimana saja tanpa harus dilakukan dikelas seperti sekolah tatap muka biasanya. Dan dapat dilakukan dengan menggunakan media apa saja yang dapat mendukung proses pembelajaran. (Cecep Kustandi, 2020). E-learning merupakan trobosan baru dalam 
dunia pendidikan untuk melakukan proses pembelajaran. Dan E-learning merupakan salah satu hasil atau wujud dari perkembangan teknologi dan informasi. Dalam Elearning pembelajran tidak mengharuskan peserta didik untuk hadir dalam kelas tatap muka guna memeperhatikan guru dalam menyampaikan materi. Dalam pengaplikasian Elearning juga mempunyai banyak manfaat seperti hemat biaya yang harus dikeluarkan suatu lembaga pendidikan karena peserta didik hanya butuh alat untuk komunikasi selain itu juga dengan pembelajaran yang seperti ini menghemat banyak waktu. (Darmawan, $2014)$.

Akibat virus Covid-19 yang terjadi belakangan ini hampir semua sekolah dan kampus di Indonesia bahkan dunia memberlakukan Pembelajaran Jarak Jauh (PJJ). Adapun dasar teori dari PJJ bisa dilihat dari defenisi yang disampaikan Mudhofir (Toto Ruhimat, 2013) menyebutkan ada empat pola pembelajaran. Pertama, pada pola yang pertama ini menerapkan proses pembelajaran yang pure ceramah dimana tidak menggunakn media pembelajaran atau alat peraga. Jadikarena ini pure ceramah jadi keberhasilan tergantung dengan kemampuan guru dalam mengkomunikasikan materi dengan menarikkepada peserta didiknya. Kedua, pada pola kedua proses pembelajaran sudah menggunakan alat bantu peraga jadi murid dengan guru terjalin interaksi untuk saling membantu. Ketiga, pola ketiga ini terjadi anatar guru dengan media dan murid jadi pada pola ini menyadari keterbatasan guru jadi tidak menjadikan satu-satunya sumber belajar tapi juga menjadikan media sebagai alat bantu guru. jadi di pola ini proses penyampaian materi yang disampaikan gurudan penyampaian materi yang tidak disampaikan secara langsung oleh guru dalam artian disini media sebagai sumber pembelajaran. Keempat, pola media dengan siswa atau pola pembelajaran jarak jauh yang menggunakn media atau bahan pembekajara yang disiapkan. Menurut model pembelajaran yang telah disebutkan, pembelajaran lebih dari sekedar mengajar (seperti model satu), karena pembelajaran yang berhasil harus memberikan banyak perlakuan kepada siswa. Peran guru dalam pembelajaran tidak hanya menjadi guru (pemberi informasi), tetapi guru harus berperan ganda dalam pembelajaran.

Agar pola pembelajaran diterapkan bervariasi maka bahan pembelajaran harus disiapkan secara bervariasi (inti dari pola ke empat ini adalah kesimpulan atau benang merah dari pola ke tiga diatas ). 


\section{Penerapan Pendidikan Jarak Jauh di SIDH Belanda Pada Masa Pandemi}

Keadaan proses belajar di masa pandemi corona di negara ini tidak berbeda jauh dengan negara - negara yang terpapar virus yang bisa dibilang sangat mematikan. Keganasan covid 19, membuat manusia untuk mengatur kembali hidupnya. Di Belanda sendiri, virus ini cukup menyebar luas serta akhirnya membuat beberapa bidang kehidupan akhirnya lumpuh. Kontak antar manusia dan manusia yang lain menjadi sangat terbatas. Tempat fasilitas public ditutup dan tidak bisa diakses, tak terkecuali dalam dunia pendidikan.

Selama Belanda lockdown, Sekolah Indonesia Den Haag juga melaksanakan pembelajaran di rumah karena selain mengikuti peraturan di Indonesia SIDH juga mengikuti peraturan di belanda, jadi sejak awal maret tahun ini untuk kelas regular sudah melaksanakan belajar dari rumah dan untuk kelas pji masih seperti biasa (dikarenakan SIDH juga selain mempunyai kelas regular juga mempunyai kelas pji), untuk kurikulum yang digunakan kelas regular dan pji sama yaitu menggunakan kurikulum k-13, dan buku yang digunakan dari BSE, akibat dari pandemi ini sebenarnya ketika ujian untuk kelas 6 para siswa dari semua negara yang belajar di SIDH hadir di SIDH untuk ujian, tapi untuk tahun ini karena adanya pandemi, maka ujian dilaksanakan secara online dan untuk ujian akhir semester juga dilaksanakan melalui google form.

Pada 20 juli 2020 ini SIDH sudah kembali di buka dan sudah melaksanakan pembelajaran seperti biasanya. Untuk dampak yang dialami akibat covid yang terjadi kemarin untuk jenjang SD di sidh yaitu ujian akhir sekolah yang kelas yang sudah direncanakan tidak bisa dilakukan.

Perubahan yang paling besar akibat pandemi dari sisi guru di awal pandemi guru terus berbenah dan SIDH sudah diuntungkan dari adanya sebagian guru yang pernah menjadi tutor pembelajaran online dan koneksi internet di Belanda sudah bagus tapi masih ada keluhan untuk koneksi internet, survey perubahan pada siswa mereka sebagian merasa kekurangan bermain pada teman nya dan juga pada praktek belum bisa dilakukan secara langsung dan hanya mengakses sumber yang relevan untuk belajar, ada juga siswa merasa senang dengan situasi itu karena merasa lebih aman dari covid-19 atau lebih santai, tantangan yang lebih sulit adalah memotivasi siswa secara online, tapi SIDH beruntung karena terbantu dengan jumlah siswa yang sedikit dan itu sangat membantu 
walaupun tetap masih ada pandangan siswa yang lebih santai yang menjadi tantangan bagi guru.

Untuk KBRI dalam hal ini dalam membantu dan mengurusi pembelajaran di masa pandemic ini sudah melakukan sanitasi lingkungan sekolah SIDH secara kesuluruhan, Untuk persiapan pembukaan sekolah, pihak SIDH sudah mempersiapkan beberapa hal antara lain:

1. Sekolah menyediakan 2 masker, (saat di sekolah boleh lepas kecuali di kendaraan umum).

2. Menyiapkan Handsanitazer

3. Cek suhu tubuh.

4. Kelas setelah pembelajaran akan dibersihkan

Untuk kurikulum SIDH tidak melakukan penyesuaian kurikulum dan tetap menggunakan metode yang sama hanya tutorial nya yang berbeda.untuk Penilaian tugas dilakukan seperti biasa tapi dilakukan secara online.

\section{Penerapan Pendidikan Jarak Jauh di SIKL Malaysia Pada Masa Pandemi}

Dimasa pandemi Covid -19 saat ini memiliki efek yang mendalam pada pendidikan teradap peserta didik. Akibatnya pada akademis pribadi seperti saat proses belajar mengajar menjadi terganggu. Adanya Social distancing ini memiliki dampak bagi sekolah, perguruan tinggi dan perusahaan harus diliburkan dan juga diperintakan untuk menerapkan WFH (Work From Home) dan pembelajaran jarak jauh. Pendidikan jarak jauh adalah suatu pembelajaran dalam proses pendidikannya berada pada lokasi yang terpisah sehingga diperlukan suatu sistem telekomunikasi interaktif untuk menghubungkan keduanya. Jadi dalam penerapan pendidikan jarak jauh yaitu sebuah tindakan yang harus dilakukan secara terpisah dan didalamnya uga memerlukan sebuah sistem telekomunikasi interaktif guna untuk mencapai tujuan bersama yang telah ditentukan. Pendidikan jarak jauh juga memiliki keuntungan antara lain materi masih tetap dapat diterima oleh peserta didik melalui media telekomunikasi dan secara tidak langsung peserta didik juga tetap dapat berinteraksi dengan guru dan peserta didik lainnya. 
Pada kementerian pendidikan Malaysia telah mempersilahkan sekolah dibuka untuk tingkatan tertentu dengan normal baru, akan tetapi di SIKL diharuskan mengikuti peraturan di Indonesia yang akan dimulai pada ajaran baru 2020/2021 pada 13 juli 2020, dengan demikian harus mengakhiri proses pembelajaran daring yang telah dilakukan SIKL selama pandemi, jadi proses pembelajaran akan kembali normal sesuai dengan SOP dimana kelas yang tidak boleh lebih dari 20 peserta didik. Pada tingkat SD ratarata jumlah siswa perkelas lebih dari 20 orang.

Standar Operasional SIKL selama covid-19 pada proses pembelajaran yaitu:

1. Gunakan masker selama disekolah

2. Orang tua diperkenankan mengantar murid sampai digerbang sekolah atau akses masuk lewat gerbang samping

3. Peserta didik memasuki lingkungan sekolah sesuai jalur yang ditentukan

4. Beraturlah dengan rapi dan jaga jarak minimal 1 meter dengan peserta didik lain

5. Suhu badan akan dicek ketika memasuki lingkungan sekolah

6. Cucilah tangan ditempat yang sudah disediakan

7. Selama di kelas belajarlah di bangku masing-masing yang sudah diatur jaraknya, pastikan selalu dalam keadaan rapi.

8. Awali kegiatan pembelajaran dengan berdoa

9. Ketika istirahat kantin tetap dibuka, akan tetapi mekanisme pembelian makanan telah diatur dengan sistem free order. Jadi perwakilan kelas akan mengambil makanan yang telah dipesan sebelumnya dan makanan dimakan dalam kelas.

10. Peserta didik dianjurkan membawa bekal sendiri dari rumah

11. Seringlah cuci tangan sampai bersih yang dikelas telah disediakan tempat cuci tangan, tempat sampah, dan alat kebersihan kelas

12. Buanglah sampah pada tempatnya dan jagalah selalu kebersihan kelas

13. Peserta didik yang telah selesai belajar dianjurkan segera pulang kerumah bila dijemput maka orang tua disediakan tempat ruang tunggu didepan gerbang sekolah. 
Mulai tahun ajaran 2020/ 2021 ini dari pihak SIKL telah menetapkan kurikulum SIKL yang telah diselaraskan sesuai dengan kondisi dan keperluan dimasa sekarang dan para guru juga dapat menggunakan aplikasi digital masing - masing.

\section{Kendala Dalam Penerapan Pendidikan Jarak Jauh di SIDH Belanda Pada Masa Pandemi}

Pandemi Covid-19 yang tejadi merubah kebiasaan yang baru atau new normal. Perubahan tersebut menyebabkan orang tua, pendidik dan peserta didik khususnya anak sekolah dasar tidak siap menghadapi keadaan tersebut. Mengingat kembali kebijakan pemerintah yang telah ditetapkan, untuk menanggulangi atau memutus rantai penyebaran virus corona yaitu baik beribadah, bekerja, serta belajar sekarang harus dilaksanakan di rumah masing-masing. Permasalahan dari peserta didik sendiri pada saat pembelajaran daring di masa pandemi, yaitu sering mengeluh karena jenuh melaksanakan kegiatan pembelajaran daring yang dilakukan di rumah setiap hari. Ada juga peserta didik yang mengatakan bahwa pembelajaran dengan daring sangat membosankan. Selain itu juga kendala sinyal, dan susahnya jika orang tua tidak bisa mengoperasikan teknologi internet. Jadi kegiatan pembelajaran cenderung tidak stabil.

Di sisi lain, di SIDH (Sekolah Indonesia Deen Haag) telah melaksanakan PJJ (Pendidikan Jarak Jauh) yang dimulai pada tahun 2008, jadi dengan sudah terbiasanya dilakukan Pembelajaran Jarak jauh, maka otomatis di masa pandemi ini ini peserta didik tidak kaget dengan adanya pembelajaran via online (daring) yang diberikan guru (pendidik), guru juga sudah mengetahui strategi-strategi yang ada ketika pembelajaran daring, tetapi biasanya yang menjadi kendala dalam pembelajaran dimasa pandemi ini adalah praktek-praktek yang ada karena jarak jauh otomatis peserta didik kesulitan untuk melakukan praktek pembelajaran. Kendala yang lain pada pembelajaran jarak jauh yaitu waktu belajarnya di persempit karena keterbatasan waktu, selain itu juga dikarenakan sebagian besar peserta didik sudah belajar disekolah lokal. Maka dengan ini diperlukan bimbingan orang tua untuk membimbing anaknya dalam proses belajar mengajar.

Sebenarnya dalam pembelajaran daring atau jarak jauh, peserta didik lebih banyak berada di rumah tidaklah seburuk apa yang kita bayangkan, apalagi jika sering berinteraksi dengan orang tua mengenai pendidikan. Jadi orang tua dapat mengawasi anaknya ketika proses belajar mengajar berlangsung secara daring. Dengan belajar dari 
rumah maka karakter peserta didik akan terbentuk, salah satunya yaitu seperti kemandirian. Disinilah peran orang tua untuk dapat membentuk putraputrinya agar memiliki karakter yang baik. Dan orang tua harus bisa menjadi seorang pendidik, menggantikan posisi guru (pendidik) di sekolahan dan sebagai life educator selama pandemi ini agar memiliki karakter yang baik dan kuat serta memiliki perlaku moral yang baik dalam diri individu (peserta didik).

\section{Kendala Dalam Penerapan Pendidikan Jarak Jauh di SIKL Malaysia Pada Masa Pandemi}

Dalam menyikapi pendidikan dimasa pandemi covid-19 semua proses pembelajaran dilakukan secara daring/online (KKL). MOOC atau Massive Open Online Course (MOOC) adalah salah satu platform e-learning atau pembelajaran secara daring dengan menggunakan teknologi yang digunakan untuk menyampaikan informasi dan orang-orang terhubung bersama. Tapi pembelajaran secara daring tersebut dilakukan tidak begitu lama yaitu hanya 4 bulan karena keadaan di Malaysia perihal covid sudah membaik, jadi proses pembelajaran kembali normal lagi namun pihak sekolah tetap menerapkan protokol kesehatan dan tetap sesuai dengan SOP yang mana satu kelas tidak boleh lebih dari 20 siswa. Dari 354 siswa yang ada di SIKL yang datang ke sekolah sekitar 200 an, tingkat SD rata-rata jumlah peserta didik perkelas lebih dari 20 orang jadi dalam proses pembelajaran langsung dibagi menjadi 2 kelompok sedangkan tingkat SMP dan SMA tetap berangkat semua karena perkelas tidak ada 20 orang .

Kendala umum yang dihadapi PJJ antara lain kesiapan sumber daya manusia, kurangnya arahan yang jelas dari pemerintah daerah, kurangnya kurikulum yang sesuai serta terbatasnya sarana dan prasarana terutama teknologi dan jaringan internet. Kesiapan sumber daya manusia termasuk dukungan dari pendidik, peserta didik dan orang tua menjadi bagian terpenting dalam pelaksaan PJJ. Dengan adanya PJJ banyak sekali keluhan dari orang tua atau peserta didik yang disampaikan kepada komisi perlindungan anak (KPAI) sebanyak 213 pengaduan. Keluhan pertama berkaitan dengan waktu tugas yang terlalu singkat dan beban kerja yang terlalu besar. Keduanya banyak tugas meringkas dan menyalin buku. Ketiga, jam belajar masih kaku. Keempat, keterbatasan 
kuota untuk mengikuti pembelajaran daring. Kelima, sebagian siswa tidak memiliki perlengkapan pribadi sehingga menyulitkan mereka untuk mengikuti ujian secara online.

Iras Aprilia menulis bahwa dalam pembelajaran secara daring sering kali ditemukan materi yang disampaikan tidak sepenuhnya dipahami, banyak peserta didik yang kebingungan saat menerima materi dari guru, walaupun kegiatan belajar-mengajar dilakukan menggunakan video call tetapi sama saja tidak bisa efektif dan juga terkadang peserta didik menjadi bosan dengan sistem belajar yang seperti itu.

Pelaksanaan PJJ di SIKL lebih banyak memberikan tekanan psikologis, tekanan pedagogis, tekanan sosial dan ekonomis bagi anak-anak dan orang tua. Oleh sebab itu SIKL menerapkan strategi PJJ yaitu "Rumah Belajar Ramah Anak" ini merupakan jawaban dari permasalahan pembelajaran selama dirumah yang diresahkan anak selama pandemi covid-19. Ada 1 point dalam rumah belajar ramah anak yaitu menyeimbangkan porsi kegiatan kurikuler dengan porsi kegiatan ekstrakurikuler, jadi kegiatan diseimbangkan antara offline dengan online. Kegiatan ekstrakurikuler bertujuan untuk merefresh otak anak dari tekanan batin yang dirasakan agar terhindar dari depresi. Kemampuan guru dalam mengintegrasikan penggunaan teknologi ke dalam pembelajaran juga akan mempengaruhi motivasi dan kemampuan peserta didik meningkat secara signifikan dalam mencapai tujuan pendidikan. Penyediaan materi yang berkualitas tinggi juga harus dilakukan oleh pendidik disegala kondisi dan situasi dalam pandemi seperti ini, hal tersebut bertujuan agar peserta didik mempunyai. Apabila materi yang diberikan untuk menarik perhatian siswa tidak monoton maka kemampuan belajarnya tinggi.

\section{KESIMPULAN}

Kemendikbud telah menerbitkan surat edaran mengenai pencegahan dan penanganan mengenai virus corona, khususnya bagi warga sekolah dan masyarakat pada umumnya. Maka dari itu pemerintah melaksanakan proses pembelajaran disekolah dengan pembelajaran dari rumah atau PJJ (pendidikan jarak jauh). Menurut Setijadi (2005:1) PJJ adalah salah satu jenis pendidikan yang peserta didiknya berpisah atau berjarak dengan gurunya, jadi pembelajaran dilakukan dengan tidak langsung. 
Di SIDH terdapat 2 kelompok kelas yaitu kelas reguler dan kelas PJJ, pada masa pandemi untuk kelas PJJ pembelajaran dilakukan masih dengan seperti biasa karena sejak tahun 2008 sudah dilakukannya pendidikan jarak jauh, tetapi masih ada keluhan untuk koneksi internet, survey perubahan pada siswa mereka sebagian merasa kekurangan bermain pada teman nya dan juga pada praktek belum bisa dilakukan secara langsung dan hanya mengakses sumber yang relevan untuk belajar, ada juga siswa merasa senang dengan situasi itu karena merasa lebih aman dari covid-19 atau lebih santai, tantangan yang lebih sulit adalah memotivasi siswa secara online, tapi SIDH beruntung karena terbantu dengan jumlah siswa yang sedikit dan itu sangat membantu walaupun tetap masih ada pandangan siswa yang lebih santai yang menjadi tantangan bagi guru.

Di SIKL penerapan pendidikan jarak jauh yaitu sebuah tindakan yang harus dilakukan secara terpisah dan didalamnya juga memerlukan media telekomunikasi interaktif guna untuk mencapai tujuan bersama yang telah ditentukan. Kemendikbud mempersilahkan sekolah dibuka untuk tingkatan tertentu dengan normal baru, jadi proses pembelajaran akan kembali normal sesuai dengan SOP. Dimasa pandemi Covid -19 saat ini memiliki efek yang mendalam pada pendidikan teradap peserta didik. Akibatnya pada akademis pribadi seperti saat proses belajar mengajar menjadi terganggu. Adanya Social distancing ini memiliki dampak bagi sekolah, perguruan tinggi dan perusahaan harus diliburkan dan juga diperintakan untuk menerapkan WFH (Work From Home) dan pembelajaran jarak jauh. Pendidikan jarak jauh adalah suatu pembelajaran dalam proses pendidikannya berada pada lokasi yang terpisah sehingga diperlukan suatu sistem telekomunikasi interaktif untuk menghubungkan keduanya.

Permasalahan peserta didik sendiri pada saat pembelajaran daring dimasa pandemi yaitu sering mengeluh karena jenuh melaksanakan kegiatan pembelajaran daring yang dilakukan di rumah setiap hari. Ada juga peserta didik yang mengatakan bahwa pembelajaran dengan daring sangat membosankan. Selain itu juga kendala sinyal, dan susahnya jika orang tua tidak bisa mengoperasikan teknologi internet. Jadi kegiatan pembelajaran cenderung tidak stabil. Namun yang menjadi kendala pada PJJ di SIDH yaitu praktek-praktek yang ada karena jarak jauh otomatis siswa kesulitan untuk melakukan praktek pembelajaran dan waktu belajarnya di persempit karena keterbatasan 
waktu. Kendala umun yang dihdapi PJJ antara lain kesiapan sumber daya manusia, kurangnya arahan yang jelas dari pemerintah, kurangnya kurikulum yang sesuai serta terbatasnya sarana dan prasarana terutama teknologi dan jaringan internet. kesiapan sumber daya manusia termasuk dukungan dari pendidik, peserta didik dan orang tua menjadi bagian terpenting dalam pelaksanaan PJJ. Pelaksanaan PJJ di SIKL banyak memberikan tekanan psikologis, pedagogis, tekanan sosial dan ekonomi bagi anak-anak dan orang tua.

\section{DAFTAR PUSAKA}

Afrillia, dkk. (2010). Minda Guru Indonesia: Pandemi Corona, Disrupsi Pendidikan dan Kreativitas Guru. Aceh: Syiah Kuala University Press.

Arifa, Fieka Nurul. (2020). Tantangan Pelaksanaan Kebijakan Belajar Dari Rumah Dalam Masa Darurat Covid 19. Vol. No. 7.

Arifin, Muhammad, dkk. (2020). Menejemen Pembelajaran Pendidikan Jarak Jaub untuk Milenial. Sukabumi: Haura publishing.

Don, Yahya. (2007). Kepemimpinan Pendidikan Di Malaysia. Kuala Lumpur: PTS Professional.

Hamdani, Farid. (2020). Artikel Review Kendala Pelaksanaan Pembelajaran Jarak Jaub Dalam Masa Pandemi.

Telupun, Dominggus. (2020). Efektivitas Penerapan Model Pembelajaran Eduitainment Untuk Memotivasi Peserta Didik Selama Pembelajaran Secara Daring di Masa Pandemi Covid-19, Jurnal Syntax Transformation. Vol. 1. No. 6.

Pramana, Ida Bagus Benny Surya Adi, dkk. (2020). Adaptasi di Masa Pandemi: Kajian

\section{Multidisipliner.}

Purandina, I Putu Yoga. (2020). Pendidikan Karakter di Lingkungan Keluarga Selama Pembelajaran Jarak Jauh di Masa Pandemi Covid 19. Jurnal Ilmu Pendidikan, Vol. 3. No. 2.

Tim Pengembang Ilmu Pendidikan FIP-UPI. (2007). Ilmu dan Aplikasi Pendidikan, (Bagian 4 Pendidikan Lintas Bidang). Jakarta : Imperial Bhakti Utama 
Warsita, Bambang. (2007) "Peranan TIK dalam Penyelenggaraan PJJ" N0. 20/XI/TEKNODIKA.

Wawancara dengan Ibu Desi Nataliani secara virtual, Selaku Guru di SIDH, pada tanggal 19 Agustus 2020.

Wawancara dengan Ibu Hilma secara virtual, Selaku Guru di SIKL, pada tanggal 27 Agustus 2020. 